\title{
Determining irreducible water saturation based on well log data and laboratory measurements
}

\author{
Wyznaczenie zawartości wody nieredukowalnej na podstawie pomiarów geofizyki \\ wiertniczej oraz wyników badań laboratoryjnych
}

\author{
Anita Lis-Śledziona, Marek Stadtmüller \\ Oil and Gas Institute - National Research Institute
}

\begin{abstract}
Unconventional resources, explored recently in Poland, require alternative methods of interpretation as the methods used in the conventional reservoir characterization often lead to misleading solutions that differ from the results of field tests and laboratory analyses. This paper presents novel methods of estimating irreducible water saturation in the tight gas sandstones based on the well $\log$ data and the results of laboratory analyses, including the NMR results. The first stage of the interpretation included calculating the quartz and shale volume, and calibrating the results with the laboratory measurements (XRD). Respectively, porosity and permeability were calculated and the pore-size distribution was evaluated. Based on porosimetry measurements, there were two porosities determined with pore-sizes below $1 \mu \mathrm{m}$ and above $1 \mu \mathrm{m}$. Based on the relationships between laboratory NMR results and parameters calculated using well log data, capillary water content and mobile water saturation was estimated. The final stage of the analysis involved the calculation of irreducible water content by the following methods: evaluating the NMR data, using the Hong model $l v$ (Hong et al., 2017), and calculating irreducible water saturation according to Zawisza's formula, and assuming that irreducible water saturation is related to pore space with pore-diameter below $\mu \mathrm{m}$. Irreducible water saturation identified with critical water saturation is an important parameter which should be taken into account when determining the water saturation. When the Montaron model is used, the critical water saturation values, Sc, are crucial for the correctly calculating the Water Connectivity Index (WCI). The aim of this paper was to assess the suitability of using the results of NMR measurements performed in the tight gas formations in determining irreducible water saturation. The recognition of pore diameters enables to determine the pore space occupied by free hydrocarbons and hydrocarbons stored in "tight", micro-pore space, the exploitation of which will require the fracturing process.
\end{abstract}

Key words: irreducible water saturation, Swir, NMR, well log data, capillary water, free water, clay bound water, tight gas formation.

STRESZCZENIE: Prowadzone obecnie w Polsce poszukiwania w skałach o charakterze niekonwencjonalnym wymagają zastosowania alternatywnych metod interpretacyjnych, gdyż metody wykorzystywane w interpretacji złóż konwencjonalnych często prowadzą do rozwiązań sprzecznych z wynikami testów złożowych i analiz laboratoryjnych. W pracy przeanalizowano zawartość wody nieredukowalnej w piaskowcach typu tight, opierając się na profilowaniach geofizyki wiertniczej oraz wynikach analiz laboratoryjnych z uwzględnieniem wyników pomiarów NMR. Pierwszy etap pracy obejmował rozpoznanie składu litologicznego i skalibrowanie objętościowej zawartości kwarcu i minerałów ilastych z wynikami badań XRD. Kolejno wyznaczono przepuszczalność i porowatość badanej formacji oraz oszacowano rozkład wielkości porów budujących przestrzeń porową. Korzystając w wyników pomiarów porozymetrycznych, obliczono także porowatość dla porów o średnicach poniżej i powyżej $1 \mu \mathrm{m}$. Opierając się na zależnościach pomiędzy wynikami pomiarów NMR oraz parametrami oznaczonymi na podstawie danych geofizyki wiertniczej, oszacowano zawartości poszczególnych rodzajów wód: związanej kapilarnej oraz wolnej. Finalnym etapem analizy było obliczanie zawartości wody nieredukowalnej różnymi metodami: na podstawie badań NMR, korzystając ze wzoru Honga $l v$ (Hong et al., 2017) oraz przyjmując jako zawartość wody nieredukowalnej wartości obliczone wg wzoru Zawiszy. Woda nieredukowalna, utożsamiana z krytycznym nasyceniem wodą, jest ważnym parametrem, którego wartości należy znać i uwzględniać podczas oznaczania współczynnika nasycenia wodą. W przypadku stosowania modelu Montarona w szacowaniu współczynnika nasycenia wodą wartości krytycznego nasycenia wodą Sc są kluczowe dla poprawnego wyznaczenia WCI (water connectivity index) - współczynnika ciągłości przepływu. Celem pracy była ocena przydatności i możliwości wykorzystania wyników pomiarów NMR wykonanych w formacjach typu tight w wyznaczaniu zawartości wody nieredukowalnej. Rozpoznanie wielkości średnic porów pozwala wydzielić potencjalną przestrzeń akumulacji węglowodorów wolnych w złożach konwencjonalnych oraz węglowodorów w formacjach typu tight, których eksploatacja wymagać będzie procesu szczelinowania.

Słowa kluczowe: współczynnik nasycenia wodą nieredukowalną, Swir, NMR, profilowania geofizyki wiertniczej, woda kapilarna, woda wolna, woda związana, formacje typu tight.

Corresponding author A. Lis-Śledziona, e-mail: lis@inig.pl

Article contributed to the Editor 21.01.2019. Approved for publication 17.04.2019 


\section{Introduction}

The aim of this paper is to determine irreducible water saturation in tight gas formation. This parameter plays a significant role in estimating hydrocarbon initially - in-place. Permeability, porosity, and irreducible water saturation are closely linked to each other. Especially the volume of irreducible water saturation have a great impact on the filtration and reservoir parameters, as this is the amount of water which cannot be removed from the formation and the reduced part of available effective porosity, preventing hydrocarbon accumulation. The accurate determination of irreducible water saturation will result in more reliable and precise well log data interpretation, which will impact the estimation of reservoir resources of oil and gas. The laboratory measurements of Nuclear Magnetic Resonance (NMR) in conventional reservoirs provide accurate levels of mobile water and irreducible water saturation which is the sum of clay bound water and capillary bound water (BVW + BVI). In this study, the results of NMR measurements and well log data were used to estimate the level of irreducible water saturation in tight sandstones. The dependence of irreducible water saturation on detailed pore structure was analyzed. Irreducible water saturation decrease with the increase of porosity and permeability; moreover the influence of pore and throat size and the volume of clay or silt have an impact on the volume of irreducible water content. In tight gas formations, the micro-pore structure is more complex, more micro-pores bound more water. There are many factors that influence the saturation of irreducible water, which should be paid attention to in the evaluation of the reservoir. The studied rocks are mostly tight sandstones and quartz arenites. Sandstones with thin interbedding of sandy-mudstones heteroliths interpreted as marginal and shelf tidal sands with tidal canals, were considered the most prospective. The thickness of this level is several dozen meters.

\section{Description of the selected research area and the input data}

The study was carried out within the sandstone formation, where irreducible water saturation was calculated. The interpretation of irreducible water saturation was performed in well O-2. The porosity of this level is very diverse: from almost "non-porosity" zones to over $20 \%$. The quartzitization of sandstones, reducing the original porosity and permeability, was mainly the result of their cementation with silica (Jaworowski, 1982). Factors having a major impact on the formation of sandstone porosity are sedimentation environment, burial depth, cementation, compaction, dissolution, and fracture susceptibility. The greatest reduction of the original porosity was due to mechanical compaction processes, which caused a reduction of porosity by $10 \%$, a cementation process that caused further reduction of porosity by another $25 \%$ and also due to a process of chemical compaction. The most important among the cementation processes was silification during eo- and mesodiagenesis in the conditions of progressing subsidence. The dissolution of feldspars and ilmenite contributed to the formation of secondary porosity. Fracture porosity is also observed in sandstones. The observed cracks can be empty or filled with carbonates, quartz or bitumen. Fractures and microstylolites were potential routes for hydrocarbon migration. The sandstones are characterized by a dual porosity system: fractures and pores (Sikorska and Jaworowski, 2007). The analyzed reservoir is the tight gas formation with a small amount of light oil (gasoline).

The wide range of available data was used in order to recognize comprehensively the properties of the analyzed medium: pore-size distribution, mineral composition analysis, capillary water, irreducible and free water saturation. The full range of the analyzed data is presented in Table 1.

Table 1. The set of data used in the interpretation of irreducible water saturation in the analyzed wells

Tablica 1. Dane wejściowe wykorzystane w wyznaczaniu współczynnika nasycenia wodą nieredukowalną w analizowanych odwiertach

\begin{tabular}{|l|l|}
\hline Well log data & $\begin{array}{l}\text { GR - gamma ray, RHOB - bulk density, } \\
\text { DT - compressional slowness, NPHI - } \\
\text { neutron porosity, LLS - shallow resistivity, } \\
\text { LLD - deep resistivity }\end{array}$ \\
\hline NMR measurements & $\begin{array}{l}\text { FFI - free fluid index, SWI_irred - clay } \\
\text { bound water, Sw capillary - capillary bo- } \\
\text { und water, PHIT - total porosity, PHIE - } \\
\text { effective porosity }\end{array}$ \\
\hline $\begin{array}{l}\text { The results of porosi- } \\
\text { metry measurements }\end{array}$ & $\begin{array}{l}\text { PHIT - total porosity, PHIE - effective po- } \\
\text { rosity, RHOB - bulk density, RHmat - gra- } \\
\text { in density, pore-size measurement }\end{array}$ \\
\hline $\begin{array}{l}\text { X-ray diffraction } \\
\text { XRD) measurements }\end{array}$ & $\begin{array}{l}\text { Volume of illite, chlorite, kaolinite, quartz, } \\
\text { piryte and carbonates }\end{array}$ \\
\hline
\end{tabular}

The first stage of data interpretation was the analysis of input data; precise depth matching the well log data to laboratory measurements, followed by the recognition of lithology by determining the volume of clay minerals and quartz. The analysis also included the calculation of the reservoir parameters of the analyzed formation: total and effective porosity, absolute permeability, both calibrated with the laboratory measurements. Resistivity-index was calculated as a ratio of the resistivity of a partially water-saturated formation (RT) and resistivity of a fully water-saturated rock. The next step was to determine the pore-size diameters and calculate the porosity 
for pore diameters above and below $1 \mu \mathrm{m}$. Finally, irreducible water saturation was estimated using 3 different methods: 1) NMR studies; 2) Hong lv formula (Hong et al., 2017);

3) Zawisza's formula to calculate irreducible water saturation.

\section{Estimation of critical water saturation using NMR measurements}

Critical water saturation in conventional reservoirs is the amount of irreducible water present in the formation. This is the amount of water which cannot be removed from the rock. In conventional reservoirs where hydrocarbons are accumulated mainly in pores of a diameter larger than $1 \mu \mathrm{m}$ it is a sum of clay bound water and capillary bound water. The amount of irreducible water saturation is connected with porosity, permeability, and grain size of the reservoir rock. Irreducible water saturation increases with decreasing permeability. In finegrained rocks, where microporosity is profound, the amount of irreducible water saturation will be higher compared to rocks where meso- and macropores dominate. These phenomena can be explained based on the fact that more water is adsorbed in very fine-grain sedimentary rocks that are mainly hydrophilic (water-wet) and have a high specific surface area. In addition, higher capillary pressures are observed in micro-pores. The high content of irreducible water saturation was observed by Trask (Trask, 1950), who stated that the original amount of water during sedimentation of sedimentary rocks reaches up to $45 \%$ of the pore volume in fine-grained well-sorted sandstone, up to $50 \%$ in mudstones, up to $80 \%$ in clays, and even over $90 \%$ in colloids (Levorsen, 1972).

In the reservoir, the majority of the bound water is either adsorbed on the surface of mineral grains or is held by capillary pressure in the capillaries of the reservoir rock (Levorsen, 1972), and it cannot be removed from the rock. Critical water saturation (Sc) achieves high values, especially in silty rocks and shale formations in which microporosity predominates, and effective porosity is very low. In contrast, "clean sandstones" or carbonates with the domination of meso- and macropores are characterized by high permeability and very low values of irreducible water. Critical water saturation can also be read from the SW vs PHIT cross-plot; this method was proposed by Bateman (Bateman, 1984). The method is based on the assumption that the product of porosity and water saturation is constant. The reservoir performance can be evaluated in terms of BVW = PHI $\cdot$ SW. Contour lines of constant bulk volume water may be used as cut-off boundaries.

To determine the content of irreducible water, the NMR measurements could also be utilized. The NMR log run can nowadays display clay bound water (BVW), irreducible water (capillary bound water, BVI), and mobile fluids (BVM). These measurements allow to calculate Swir for conventional reservoirs as the sum of BVW + BVI.

\section{Determining irreducible water saturation in tight sandstones}

Estimating the amount of irreducible water saturation in conventional reservoirs could be calculated from Zawisza's (Zawisza and Nowak, 2012) formula or based on NMR measurements.

On the other hand, if we consider tight sandstones, the dual porosity system should be taken into account. Hydrocarbons in tight gas reservoirs are present in macroporosity (pore-sizes larger than 1um) and in microporosity (pore-sizes below $1 \mathrm{~m}$ ). In conventional reservoirs, usually, the porosity of pore-sizes below 1 um is filled with capillary bound water, while in tight gas reservoirs part of this water is removed due to higher capillary pressure and replaced with gas (Klaja and Gąsior, 2010). When dealing with unconventional reservoirs it is very important to estimate the level of free water, capillary bound water, and clay bound water. The recognition of pore-sizes may also be useful during irreducible water saturation. Figure 1 shows the modeled capillary pressure curves of different reservoir types. Capillary pressure curves are important in defining reservoir types.

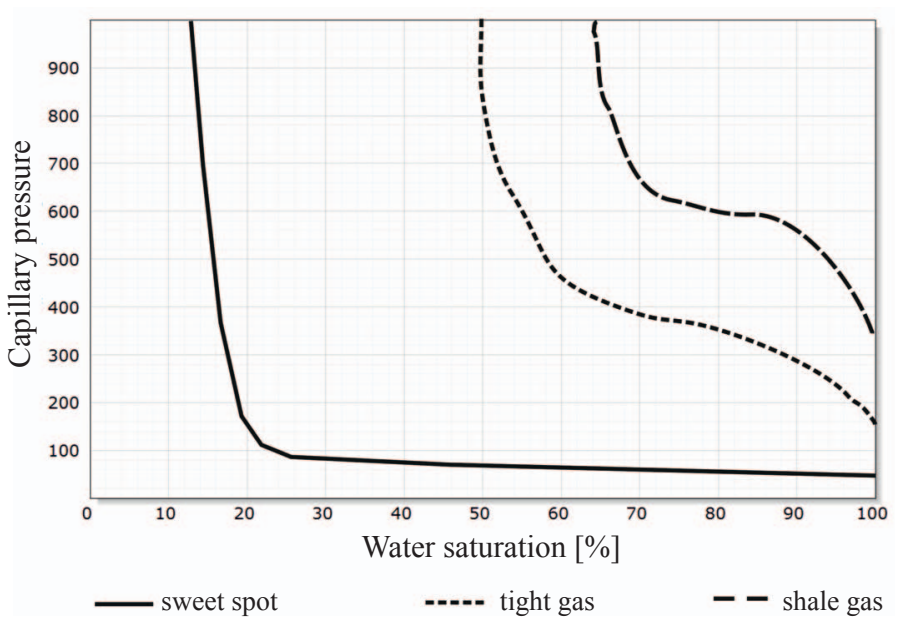

Fig. 1. Capillary pressure curves for 3 different reservoir types (adapted from Moore, 2016)

Fig. 1. Modelowe krzywe ciśnień kapilarnych dla trzech różnych typów złóż (zmodyfikowanie na podstawie Moore, 2016)

There are three capillary pressure-water saturation relationships. The sweet spot sandstones are conventional reservoir sandstones within the thicker interval of the tight gas sandstones and show the lowest irreducible water saturation (15-20\%) along with the lowest capillary pressure profile. The tight gas sandstones have higher irreducible water saturation (50\%) and 
higher capillary pressure than sweet spot sandstones. The shale and siltstones show the highest irreducible water saturation (more than 60\%) and the highest capillary pressure. The tight gas sandstones could have relatively high water saturation but still will be capable of water and free gas production (Moore et al., 2016).

The irreducible water saturation coefficient is closely related to the mineral composition, especially the volume of clay minerals, filtration, and reservoir parameters of the rock: permeability $(K)$ and porosity $(\mathrm{PHI})$. Based on the relationship between the irreducible water saturation and the pore structure coefficient $K / \phi$, in Suxie's area, the model of irreducible water saturation was established by Hong lv (Hong et al., 2017). The model shows that saturation with irreducible water is higher in rocks with worse reservoir parameters, low permeability, low porosity, and high shale volume.

$$
S_{W I I}=74.136 \cdot(\sqrt{K / \phi})^{-1.782} R^{2}=0.7693
$$

An appropriate $T_{2}$ cut-off determination is difficult, and currently there is no optimum method to acquire $T_{2}$ cut-off from NMR $T_{2}$ distribution. A default $T_{2}$ cut-off of $33 \mathrm{~ms}$ has been proposed for clastic reservoirs and $92 \mathrm{~ms}$ for $\mathrm{T}_{2}$ carbonate reservoirs (Moris et al., 1993; Coates et al., 2008; Xiao, 2008). However, in practical applications, defining $33 \mathrm{~ms}$ as $T_{2}$ cutoff is not always accurate in clastic reservoirs, especially in tight gas sandstones. Analyses of the capillary water content in "tight" gas formations also showed that the capillary bound water volume from NMR measurements is overestimated. For tight hydrocarbon sands, if the pore space is occupied by light oil or natural gas, the shape of the $T_{2}$ spectrum will be distorted due to the contribution of bulk relaxation of light oil and diffusion relaxation of natural gas (Xiao et al., 2011). Figure 2 presents the $T_{2}$ spectra of an unconventional sample.

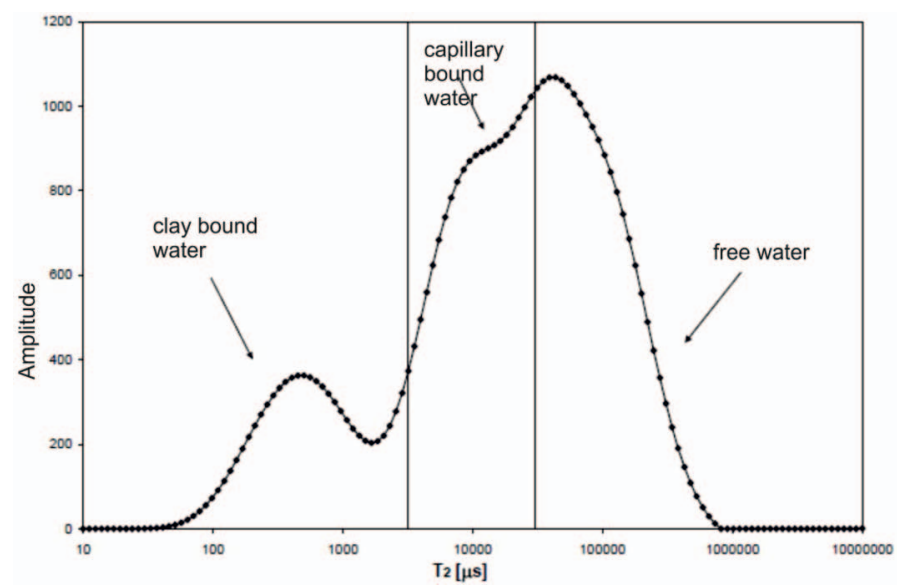

Fig. 2. Saturation distribution based on NMR measurements. $T_{2}$ spectra of an unconventional sample

Fig. 2. Rozkład nasyceń na podstawie pomiarów NMR. Widmo $T_{2}$ dla próbki ze złoża niekonwencjonalnego
The analysis of 155 samples from different reservoir regions in North America (Timur, 1968) showed that the absolute permeability $(K)$ of the analyzed rocks is proportional to the porosity $(\phi)$ and inversely proportional to the saturation of irreducible water (Swir) (2). The developed model is as follows:

$$
K=0.136 \cdot \frac{\phi^{4.4}}{S w i r^{2}}
$$

where: $K$ is the rock permeability in units $10^{-3} \mathrm{~mm}^{2}, \phi$ is the rock porosity in fraction, and Swir is irreducible water saturation, in fraction (Timur, 1968).

\section{The analysis of the pore diameter, the content of clay bound water, capillary bound water, and free/mobile water in the 0-2 well}

Depending on the pore-size distribution and the reservoir pressures, the available porosity may be filled with different types of water. Total porosity is always reduced by the amount of irreducible water present in the formation (Swir) also called the critical water saturation by Montaron (Montaron, 2009). Critical water saturation is determined by a special core analysis and is defined as the maximum water saturation that a formation with a given permeability and porosity can retain without producing water. This water, although present, is held in place by capillary forces and will not flow. The critical water saturation should be compared to the reservoir's in-place water saturation calculated from downhole electric logs. If the in-place water saturation does not exceed the critical value, then the well will produce only hydrocarbons. These saturation comparisons are particularly important in low permeability reservoirs where critical water saturation can exceed $60 \%$ while still producing only hydrocarbons.

\section{Determining critical water saturation, as a sum of clay and capillary bound water}

In conventional reservoir rock with high porosity and permeability where the meso- and macropores dominate, Zawisza's model works well to estimate the level of Swir. The literature assumes (Nelson, 2009) that in conventional reservoirs the poresizes are larger than $2 \mu \mathrm{m}$, in tight gas formations the size of the pore diameter ranges from about $0.03-2 \mu \mathrm{m}$, and in shales from 0.005 to $0.1 \mu \mathrm{m}(5 \mathrm{~nm})$. Methane particles $(0.00038 \mu \mathrm{m})$ are small enough to accumulate in very small pores (Nelson, 2009). The tight oil and tight gas formations are defined by low porosity (below $10 \%$ ), permeability not exceeding $0.1 \mathrm{mD}$, and higher capillary pressure. Capillary pressure is important in 
reservoir engineering because it is a major factor controlling the fluid distributions in a reservoir rock; higher capillary pressure will displace water out of smaller pores.

The pore-size distribution in $\mu \mathrm{m}$ was estimated based on the correlation of the effective porosity with the pore diameter measured by the mercury porosimetry method. The correlations (three correlation lines were drawn) are presented in Figure 3. The pore-size distribution obtained on the basis of the above correlation is presented as a histogram (Fig. 4).

In tight gas formations the system of double porosity was considered: macro-

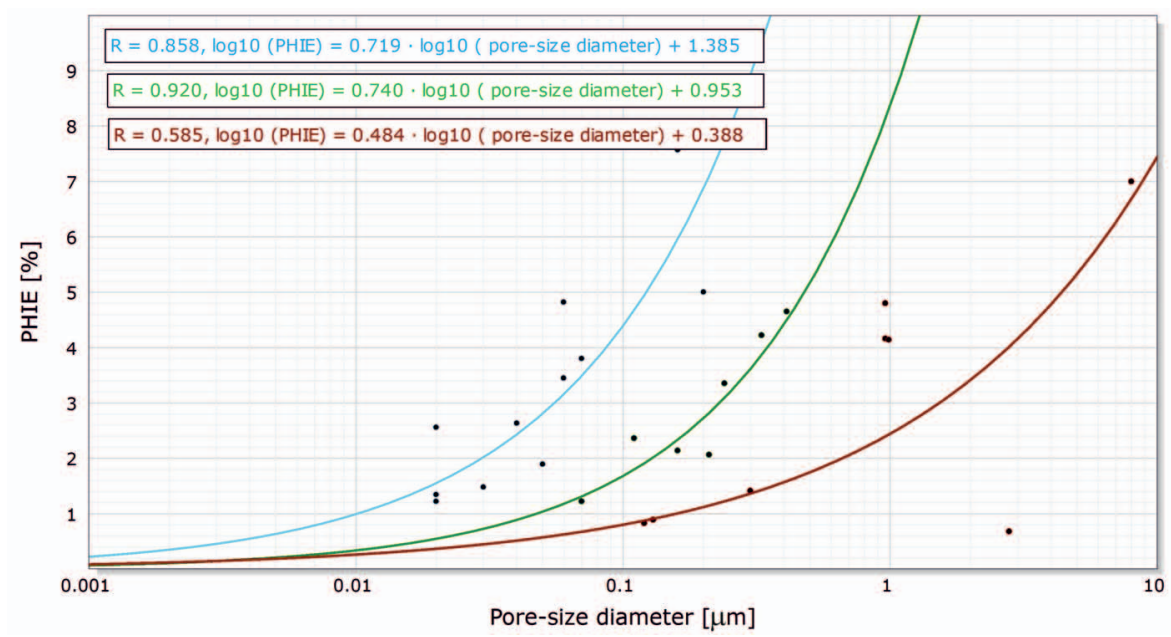

Fig. 3. Correlation between measured effective porosity and pore-size diameter

Fig. 3. Korelacja pomiędzy pomierzoną porowatością efektywną, a średnicą porów porosity above $1 \mu \mathrm{m}$ filled with free water and conventional hydrocarbons, microporosity $0.01-1 \mu \mathrm{m}$, in conventional reservoir often treated as not effective, filled with capillary bound water and porosity of the nanoscale below 10 nanometers $(0.01 \mu \mathrm{m})$ with pores filled mainly with clay bound water. The pore diameters below 1 micrometer are too small to allow free flow of water. Therefore, knowledge of the pore-size distribution allows to estimate the saturation of free, capillary and bound water.

As it can be seen from the above histogram (Fig. 4), the majority of pore space is built of micro-pores with a diameter of $0.01-1 \mu \mathrm{m}$, only a small part of the pores is larger than $1 \mathrm{mi}-$ crometer. In the analyzed sandstones, laboratory measurements of NMR were performed. As a result, the level of clay bound water, capillary bound water and mobile water saturation was estimated. Based on the correlation between well log data and the results of NMR measurements, the continuous irreducible water saturation line was determined.

The following data were calculated:

- PHI $1 \mu \mathrm{m}$ - porosity over $1 \mu \mathrm{m}$,

- PHIE - effective porosity,

- PHIT - total porosity,

- SWI_irred - irreducible water saturation - mainly bound in clays and very small pores, determined on the basis of correlation of the amount of bound water SWI_irred determined in NMR laboratory measurements with laboratorymeasured effective porosity (Fig. 5).

SWI_H - irreducible water saturation calculated using Hong's equation (3), (SWI_H) indicated very high SWI values above $80 \%$. The equation required calibration to the currently interpreted data. It was assumed that at non-productive intervals of high shale volume content where the amount of capillary water in total water saturation is very small, SWI_H = clay bound water $(\mathrm{CBW})=$ SWI_irred. Figure 6 shows irreducible water saturation determined using NMR data (SWI_irred) with

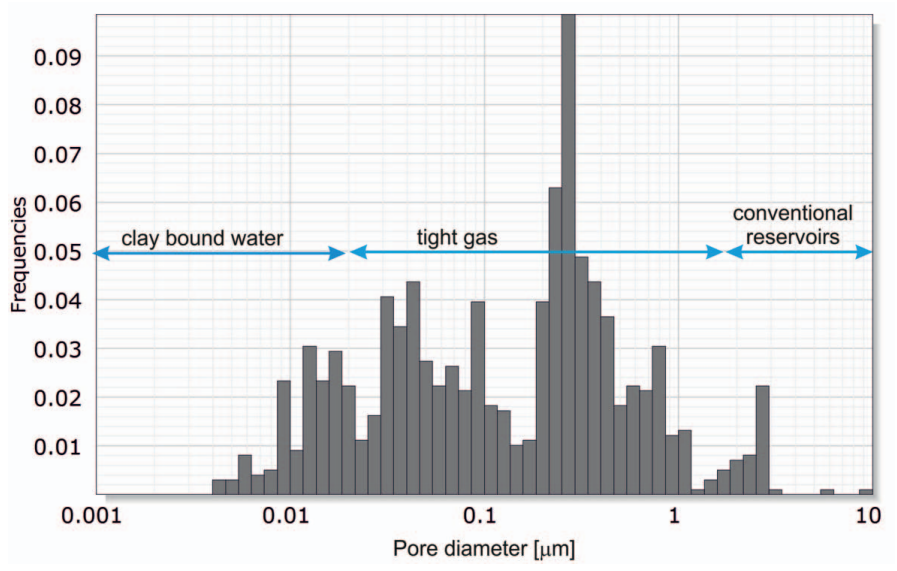

Fig. 4. Pore-size distribution in well O-2

Fig. 4. Rozkład wielkości porów w odwiercie O-2

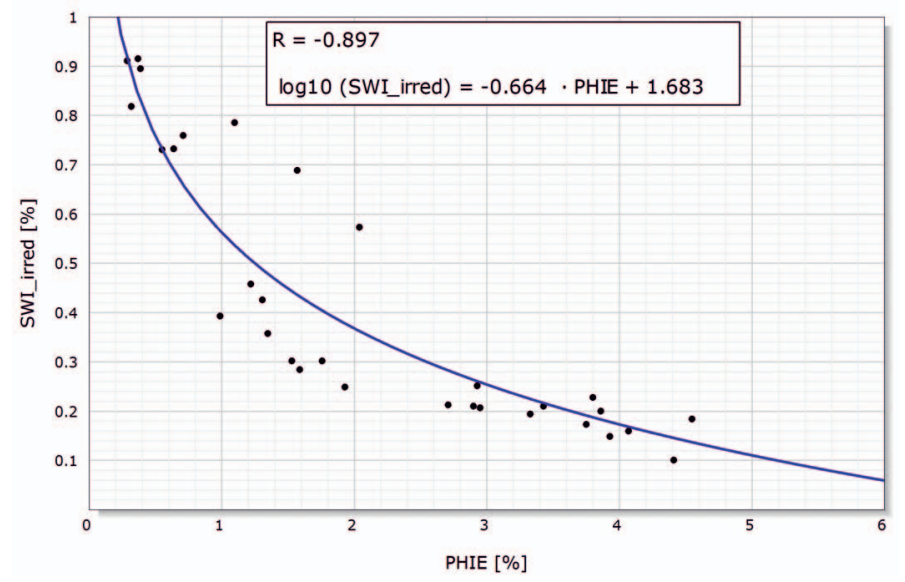

Fig. 5. The correlation of clay bound water (NMR) with calculated effective porosity

Fig. 5. Korelacja pomiędzy wodą związaną w minerałach ilastych (NMR), a wyliczoną porowatością efektywną

a pore structure index $\sqrt{k / \phi}$. The curve in red is determined by Hong's equation, while the green color line shows the curve after modification, where calibration constants were changed. 

$S W I_{-} H=74.136 \cdot\left(\sqrt{\frac{K}{\phi}}\right)^{-1.782}$
(3) - Hong's equation
$S W I_{-} H=54 \cdot\left(\sqrt{\frac{K}{\phi}}\right)^{-1.4}$
(4) - the equation after modification

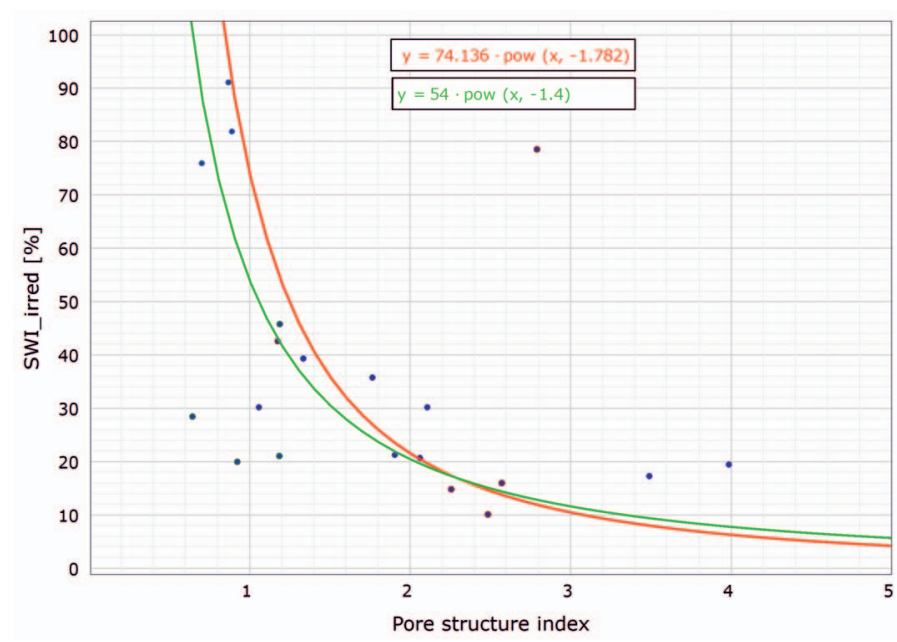

Fig. 6. The modeled curves show the relation between the pore structure index and clay bound water (from NMR). The red curve is the primary Hong's equation curve and green curve is the curve after modification

Fig. 6. Modelowe krzywe wskazujące zależność pomiędzy wskaźnikiem struktury porowej, a zawartością wody związanej w iłach (NMR). Czerwona krzywa jest pierwotną krzywą wyznaczoną z równania Honga, natomiast krzywa koloru zielonego to krzywa wyznaczona na podstawie zmodyfikowanego równania Honga

Swir Zawisza - capillary water saturation based on Zawisza's formula (with reference to effective porosity); it is irreducible water saturation without nanopores and clay bound water included.

SW_free_FIN - the coefficient of "free" water saturation, the part of porosity which is available for mobile water and free hydrocarbons accumulation. The curve was determined based on NMR measurements.

SW PHI1 $\mu \mathrm{m}$ - mobile water saturation; it was determined based on porosimetry measurements, as space where the pore diameters exceed 1 micrometer.

\section{Results and discussion}

Saturation coefficients for particular types of water are related to total porosity. The sandstones in the O-2 well are saturated with gas and condensate. The results of tests performed in this well confirmed its gas-bearing capacity. Moreover, none of the three performed tests showed the inflow of water, only gas, and gasoline.
The first and seconds tracks in Figure 7 show clay and quartz volume calculated and calibrated with XRD measurements. Track 3 presents the formation resistivity (RT) curve and resistivity for $100 \%$ water saturation rock $\left(\mathrm{R}_{0}\right)$. The fourth track shows calculated total porosity (PHIT), effective porosity (PHIE), and porosity for pore diameter above $\mu \mathrm{m}$. Tracks $5-8$ show water saturation: mobile/free water, irreducible water saturation: capillary bound water and clay bound water, without taking into account the presence of hydrocarbons.

Track 5 presents water saturation, calculated using NMR measurements correlated with well log data (porosity and shale volume). Track 6 presents the same irreducible water saturation as track 5 , but the mobile/free water saturation was calculated based on mercury porosimetry, as the porosity where pore diameters exceed $1 \mu \mathrm{m}$. Track 7 shows capillary water-filled pores of a diameter below $1 \mu \mathrm{m}$ and capillary water calculated using Zawisza's formula. Water saturation in this track is related to effective porosity. Both capillary water content presented on the histogram (Fig. 8) indicate that capillary water levels estimated using two independent methods are very similar.

$$
\text { SW_below_1 } \mu \mathrm{m}=(1-\text { PHI_of pore diameter }>1 \mu \mathrm{m}) / \text { PHIE }
$$

The last track of Figure 7 presents irreducible/critical water saturation (SWI H = clay bound water and capillary bound water) calculated using the modified Hong's equation (Hong et al., 2017), which allowed a better estimation of irreducible water saturation, as the sum of clay and capillary bound water. The area marked in brown is porosity below $1 \mu \mathrm{m}$, the area marked in blue is porosity filled with free water (NMR tests).

\section{Conclusions}

The results of NMR laboratory tests correlated with well $\log$ data enable to estimate the content of free, capillary and irreducible water saturation. NMR laboratory measurements may be helpful in estimating the level of irreducible water saturation, which is the sum of BVW and BVI, however, the results of NMR tests in the tight beds require an appropriate selection of the $T_{2}$ cut-off time. Assuming a cut-off time $T_{2}$, such as for classic sandstones, we will obtain overestimated values of irreducible water $(\mathrm{BWV}+\mathrm{BVI})$. In the analyzed borehole, Hong's method linking the Swir with the pore structure index proved to be an effective method for estimating irreducible water saturation, the coefficients in the equation were modified in such a way that in the intervals where shale volume is high, the capillary water fraction is negligible and Swir $(\mathrm{BVI}+\mathrm{BVW}) \approx \mathrm{BVW}$. The analysis of porosimetry data allowed to estimate porosity below $1 \mu \mathrm{m}$, which showed a good 


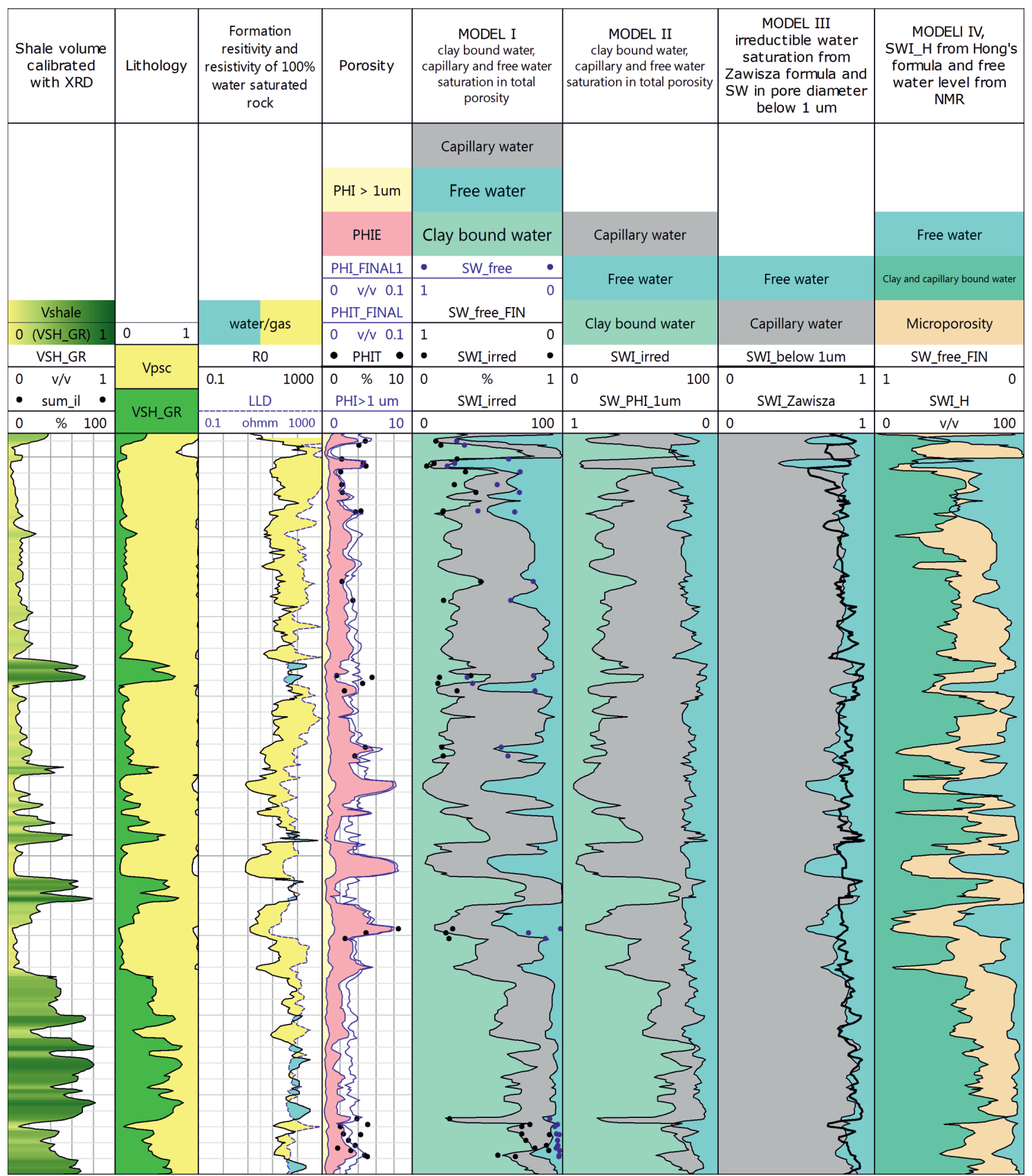

Fig. 7. Reservoir level interpretation in O-2 well. Porosity and irreducible water saturation; points - laboratory results

Rys. 7. Interpretacja poziomu zbiornikowego odwiertu O-2. Porowatość i nasycenie wodą nieredukowalną; punkty - wyniki pomiarów laboratoryjnych

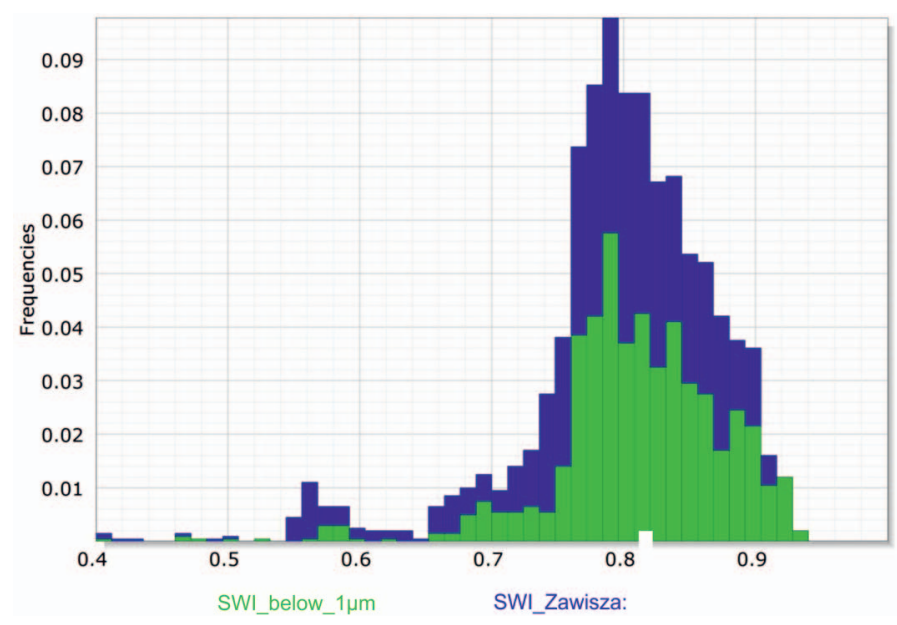

Fig. 8. Histograms of capillary water saturation calculated from Zawisza's formula and as water saturation in the micro-pores with a diameter below $1 \mu \mathrm{m}(5)$

Rys. 8. Histogram nasycenia wodą kapilarną wyliczoną na podstawie równania Zawiszy oraz jako nasycenie wodą w mikroporach o średnicy poniżej $1 \mu \mathrm{m}(5)$ 
correlation with the amount of capillary water determined from Zawisza's model.

Combining comprehensive information of porosimetry data, NMR measurements, Rock Eval data and well log data allowed to better understand the filtration and accumulation capabilities of the analyzed tight sandstones.

This paper was written on the basis of the statutory work entitled: Szacowanie wodonasycenia w skałach "non Archie" (Water saturation estimation in non - Archie rocks) - the work of the Oil and Gas Institute - National Research Institute was commissioned by the Ministry of Science and Higher Education; order number: 0042/SG/18, archive number: DK-4100-42/18.

\section{Literature}

Bateman R.M., 1984. Cased-hole log analysis and reservoir performance monitoring. Boston: IHRDC Press: 380.

Coates G.R., Xiao L.Z., Primmer M.G., 2010. NMR logging principles and applications, Huston: Gulf Publishing Company: 200: 1-200.

Hong L., Fuqiang L., Liang C., Chao L., Jie L., Heping Y., 2017. Research on evaluation method for water saturation of tight sandstone in Suxi region. IOP Conference Series Earth and Environmental Science, 64(1): 012040.

Klaja J., Gąsior I., 2010. Ilościowa ocena przestrzeni porowej zajętej wodą związaną w iłach, z wykorzystaniem metody magnetycznego rezonansu jądrowego. Nafta-Gaz, 3: 178-188.

Jaworowski K., 1982. Warunki sedymentacji osadów prekambru i kambru w północnej Polsce. Przegląd Geologiczny, 30: 220-224.

Levorsen A.I., 1972. Geologia ropy naftowej i gazu ziemnego. Warszawa: Wydawnictwa Geologiczne: 224-252.

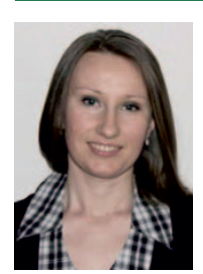

Mgr inż. Anita LIS-ŚLEDZIONA

Asystent w Zakładzie Geologii i Geochemii Instytut Nafty i Gazu - Państwowy Instytut Badawczy ul. Lubicz 25 A

31-503 Kraków

E-mail: anita.lis@inig.pl
Moore W.R., Zee Ma Y., Pirie I., Zhang Y., 2016. Tight gas sandstone reservoirs, part 2: petrophysical analysis and reservoir modeling. Unconventional Oil and Gas Resources Handbook: 429-448. DOI:10.1016/B978-0-12-802238-2.00015-8.

Montaron B., 2009. Connectivity Theory - A new approach to modeling Non-Archie rocks. Petrophysics, 50(2): 102-115.

Moriss C.E., Maclnnis J., Freedman R., Smaardyk J., Straley C., Kenyon W.E., Vinegar H.S., Tutunjian P.N 1993. Field Test of an Experimental Pulsed Nuclear Magnetism Tool. The $34^{\text {th }}$ SPWLA Annual Logging Symposium, Paper GGG.

Nelson P.H., 2009. Pore throat sizes in sandstones, tight sandstones, and shales. American Association of Petroleum Geologists Bulletin, DOI: 10.1306/10240808059.

Sikorska, M., Jaworowski, K., 2007. Ewolucja porowatości w piaskowcach kambru z polskiej części Morza Bałtyckiego. Biuletyn Państwowego Instytutu Geologicznego, nr 427, 79-110

Timur A., 1968. An Investigation Of Permeability, Porosity, And Residual Water Saturation Relationships. The $9^{\text {th }}$ SPWLA Annual Logging Symposium, Paper J.

Trask P.D., 1950. Dynamics of Sedimentation, in Applied Sedimentation. John Wiley and Sons, New York, Pp 3-40

Xiao, Z.X., 2008. Analysis of methods for determining NMR T_(2cutoff) and Its Applicability. Prog. Geophys., 23: 167-172.

Xiao L., Mao Z. Q., Jin Y., 2011. Calculation of Irreducible Water Saturation (Swirr) from NMR Logs in Tight Gas Sands. Applied Magnetic Resonance, 42: 113-125. DOI: 10.1007/ s00723-011-0273-X.

Zawisza L., Nowak J., 2012. Metodyka określania parametrów filtracyjnych skał na podstawie kompleksowej analizy danych geofizyki otworowej. Kraków: Wydawnictwa AGH: 122.

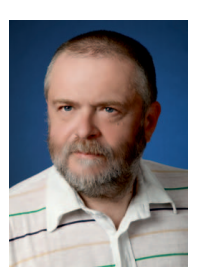

Mgr inż. Marek STADTMÜLLER

Główny specjalista inżynieryjno-techniczny

w Zakładzie Geologii i Geochemii

Instytut Nafty i Gazu - Państwowy Instytut Badawczy

ul. Lubicz $25 \mathrm{~A}$

31-503 Kraków

E-mail: marek.stadtmuller@inig.pl 